\title{
Feeding visit time of fruit-eating birds in Cerrado plants: revisiting the predation risk model
}

\author{
Igor Aurélio Silva ${ }^{1,3}$; Rodolfo Antônio de Figueiredo ${ }^{2}$ \& Dalva Maria da Silva Matos 1
}

\begin{abstract}
'Departamento de Botânica, Universidade Federal de São Carlos. Caixa Postal 676, 13565-905 São Carlos, São Paulo, Brasil.
${ }^{2}$ Coordenadoria Especial para o Meio Ambiente, Universidade Federal de São Carlos. 13565-905 São Carlos, São Paulo, Brasil.

3 Corresponding author. E-mail: igor6cordas@yahoo.com.br
\end{abstract}

\begin{abstract}
Fruiting plants that attract frequent visits by fruit-eating birds tend to be predictable patches for a predator. Consequently, the risk of a predator attack increases the longer a bird stays on a fruiting plant. We tested whether large and cryptic species of fruit-eating birds spend more time per feeding visit than smaller and conspicuous ones in fruiting plants of the Brazilian Cerrado. Data were obtained from the literature for eight fruiting plant species and from field observations of birds feeding on fruits of Zanthoxylum rhoifolium (Rutaceae). We searched for a positive linear relationship between the mean visit time and the total length of the species, considering bird color as a covariate. Feeding visits of the large and cryptic bird species lasted longer than feeding visits of small and conspicuous species. Large birds may be safer from predators because large predators are less common. Cryptic birds may be difficult to be detected by predators and, consequently, may be less likely to be attacked by predators than conspicuous birds. Thus, our results provide support to the hypothesis that vulnerable bird species spend less time foraging in fruiting plants.
\end{abstract}

KEY WORDS. Body size; crypsis; frugivory; Zanthoxylum rhoifolium.

\begin{abstract}
RESUMO. Tempo de visita de aves que comem frutos em plantas de Cerrado: revisitando o modelo do risco de predação. Plantas em frutificação atraem visitas freqüentes de aves que comem frutos e tendem a ser manchas previsíveis para um predador. Conseqüentemente, o risco de ataque de um predador aumenta com o tempo de permanência de uma ave frugívora em uma planta com frutos. Neste estudo, testamos se espécies de aves grandes e crípticas passam mais tempo por visita de alimentação em plantas em frutificação que espécies pequenas e conspícuas. Obtivemos dados da literatura para oito espécies de plantas do Cerrado e também de observações em campo de aves que se alimentam de frutos de Zanthoxylum rhoifolium (Rutaceae). Procuramos por uma relação positiva entre o tempo médio de visita e o comprimento total das espécies de aves, considerando a cor das espécies como uma co-variável. A duração das visitas de espécies grandes e crípticas foi maior que a duração de visitas de aves pequenas e conspícuas. Aves grandes devem correr menos risco de serem predadas porque predadores grandes são menos comuns. Aves crípticas, por sua vez, devem ser difíceis de serem detectadas por predadores e, conseqüentemente, a probabilidade de serem atacadas deve ser menor. Portanto, nossos resultados provêm apoio à hipótese de que espécies de aves vulneráveis passam menos tempo forrageando em plantas com frutos.
\end{abstract}

PALAVRAS-CHAVE. Tamanho de corpo; camuflagem; frugivoria; Zanthoxylum rhoifolium.

One major aspect of the behavior of fruit-eating birds that affects seed dispersal is the amount of time they spend on the fruiting plants where they feed. The more time birds spend per feeding visit, the more seeds they may deposit beneath the plant (Howe \& SMALlwood 1982), where there is a higher mortality risk for seeds and seedlings (Augspurger \& Kelly 1984). Alternatively, when bird visits are short, they are more likely to carry seeds away from the parent plant. In this case, it results in a less clumped distribution of seeds, thus reducing density-dependent mortality (Howe \& SMALLwood 1982). As a consequence, the success of establishment of bird-dispersed plants may be affected by the time fruit-eating birds spend visiting them.

Howe (1979) proposed a theoretical model that predicts the duration of feeding visits by frugivorous birds in a fruiting plant based on predation risk. According to his model, the duration of visits by frugivorous birds is determined by the vulnerability of each species to predation (Howe 1979). A fruiting plant that attracts frequent and conspicuous visits by frugivorous birds tends to be a rich and predictable patch from the predator's perspective (Schoener 1971). As a result, the overall risk of a predator attack increases the longer a bird stays in a fruiting plant 
(SCHOENer 1971). Howe (1979) also argued that birds that are large relative to predators will be expected to be less vulnerable, because small predators are more common than large predators and prey size covaries with predator size. Consequently, large birds are likely to spend more time in fruiting trees than smaller birds. Pratt \& STILES (1983) considered additionally the coloration of the birds as a vulnerability factor. According to them, cryptically colored birds should be less vulnerable to predation and, therefore, may also spend more time per visit in fruiting trees than conspicuously colored birds (PratT \& Stiles 1983).

The diet of birds may also influence the duration of feeding visits in birds, so that omnivorous species are expected to spend less time feeding than frugivorous ones. To satisfy their nutritional needs, omnivorous species have to diversify their diets, spending less time feeding in a particular plant species (Howe \& Estabrook 1977, Johnson et al. 1985). Additionally, the mode in which birds manipulate fruits may influence the time of their visits (Howe \& Estabrook 1977, Johnson et al. 1985). Birds that swallow whole fruits are expected to spend less time per visit. They are likely to satisfy their needs quicker than the birds that, for example, mash the fruit before swallowing the seeds (Howe \& EsтавRoок 1977).

The Brazilian Cerrado is the largest savanna of South America, and once covered about two million $\mathrm{km}^{2}$, mainly in the Brazilian Central Plateau (Gottsberger \& SilberbauerGotTsberger 2006a). Most of its plant species are zoochorous, and birds are the main seed dispersers in Cerrado (GotTsberger \& Silberbauer-GotTsberger 2006b). However, the great majority of the bird species seems to be generalist and the fruits constitute only a part of their diet (Gottsberger \& SilberbauerGotTSBERgER 2006b). In this work, we tested whether large and cryptically-colored species of fruit-eating birds spend more time per feeding visit than smaller and conspicuous ones in fruiting plants of the Brazilian Cerrado. Data were obtained from the literature for eight fruiting plant species and from field observations of birds feeding on fruits of Zanthoxylum rhoifolium Lam. (Rutaceae). Additionally, we tested whether the diet of bird species and the size and type of the fruit influence the duration of feeding visits of birds in fruiting plants of Cerrado.

\section{MATERIAL AND METHODS}

\section{Fruit-eating birds in Zanthoxylum rhoifolium}

Zanthoxylum rhoifolium is a deciduous tree species that grows up to $12 \mathrm{~m}$ tall. It is a common and widespread tree in cerrado and forest areas in all central and south Brazil (DAS Chagas e Silva \& Soares-Silva 2000, Oliveira-Filho et al. 2001, Neto et al. 2002, Bridgewater et al. 2004). The fruit is a spherical capsule, black when ripe, about $5 \mathrm{~mm}$ in length and $5 \mathrm{~mm}$ in width. Seeds are small, about $3 \mathrm{~mm}$ long and $3 \mathrm{~mm}$ wide, with no aril, and with a hard coat (Silva \& PaOli 2000).

We observed the birds feeding on $Z$. rhoifolium fruits in a cerrado site of about 125 ha, at the Universidade Federal de São Carlos $\left(21^{\circ} 58^{\prime}-22^{\circ} 00^{\prime} \mathrm{S}, 47^{\circ} 51^{\prime}-47^{\circ} 52^{\prime} \mathrm{W}\right)$, located in São Carlos municipality, state of São Paulo, southeastern Brazil. Regional climate is highly seasonal, with a wet summer from October to March, and a dry winter from April to September. Annual rainfall is $1,339 \mathrm{~mm}$ and mean annual temperature is $22.1{ }^{\circ} \mathrm{C}$.

We monitored three fruiting individuals of $Z$. rhoifolium, which were about $2 \mathrm{~km}$ from each other, on different days from December 2005 to January 2006. The trees were located near gallery forests, at the limit of an upland cerrado area. The observations lasted from 2 to $6 \mathrm{~h}$, between $0500 \mathrm{~h}$ and $1800 \mathrm{~h}$, totaling $65 \mathrm{~h}$. For each bird visit, we recorded the species and the duration of the visit. Observations in which we could not determine the identity of the bird and the time it entered or departed from the focal tree were excluded from the analysis.

\section{Data analysis}

We performed a broad survey of published data on frugivory in cerrado. We recorded the bird species that feed on fruits or seeds of eight cerrado plant species: Copaifera langsdorffii Desf. (MotTa-Junior \& Lombardi 1990), Davilla rugosa Poir. (FranCisco \& Galetti 2002a), Faramea cyanea Müll. Arg. (Melo et al. 2003), Ocotea pulchella Mart. (Francisco \& Galetti 2002b), Palicourea rigida H.B.K. (WüthERIch et al. 2001), Pera glabrata Schott (Francisco et al. 2007), Rapanea lancifolia Mez (Francisco \& GaletTI 2001), and Struthanthus concinnus Mart. (GUERRA \& MARINI 2002). The total time of observations was respectively 41, 60, 24, 72, $76,60,60$, and $80 \mathrm{~h}$. The number of observed plants was respectively 4, 3, 4, 4, 20, 5, 3, and 8 . All cited studies were conducted in the field, where the authors recorded the bird species and the duration of the visits with similar sampling methods.

We computed the mean time per visit for each bird species based on the information from published papers and our own observation with Z. rhoifolium. We excluded from the analysis the bird species with less than three sampled individuals. We used the total length of the bird species, as a surrogate for body size. We obtained data on total length of the bird species from SICK (1997). For color comparisons, we classified each bird species as cryptic or conspicuous. Crypsis is a background specific adaptation, so that increased crypsis in one microhabitat is expected to decrease crypsis in another one (MeriLaita et al. 2001). Hence, we classified as cryptic only those birds in which the colors of the back, front and belly were similar to plant colors, that is, brown, gray, and green-feathered birds. On the contrary, the conspicuous birds were those with black, blue, red and yellow colors from back, front or belly (BAKER \& PARKER 1979). In the cases of sexual differences in bird colors, we classified the bird species according to the male color, which is generally more conspicuous than the female color (GöTMARK 1993).

We expected visit duration to be positively related to body length, and to be higher among cryptic species. The relationship between mean visit duration and total length of the bird species, considering color as a covariate, was analyzed using an ANCOVA (Gotelli \& ElLISON 2004). Mean visit time was square root transformed to satisfy the assumption of the normal distribution of residuals. 
To assess whether birds with generalist diet spend less time per feeding visit, we classified the bird species in frugivorous, insectivorous, and omnivorous species according to Motta-Junior (1990): frugivorous species present a diet with three quarters of fruits; insectivorous species present a diet with three quarters of insects and one quarter of fruits and other arthropods; and omnivorous species present a diet with similar proportion of fruits, insects, and other arthropods (MоттAJunIOR 1990). Then, we analyzed the relationship between mean visit duration and total length of insectivorous and omnivorous birds, considering color as a covariate (ANCOVA, GotelLI $\&$ ELLISON 2004). As in the previous analysis, mean visit time was square root transformed.

Finally, we assessed whether the size and type of the fruit influence the duration of feeding visits of birds. We used these fruit characteristics as a surrogate for the manipulation time of fruits by birds. Birds should spend less time manipulating small fruits than large fruits. We obtained the length of the fruits from literature (Tab. I), and classified them into dehiscent capsules or drupes. The fruit of Copaifera langsdorffii was included in the dehiscent capsule type. Then, we analyzed the relationship between mean visit time and fruit length, considering fruit type as a covariate (ANCOVA, Gotelli \& Ellison 2004). Again, mean visit duration was also square root transformed.

\section{RESULTS}

A total of 135 feeding visits were recorded in Zanthoxylum rhoifolium. We observed 15 bird species feeding on its fruits (Tab. II). We did not observe any other animal feeding on $Z$. rhoifolium fruits. Besides the species recorded in $Z$. rhoifolium, we obtained in the literature the mean visit time for other 24 bird species that feed on fruit of cerrado plants (Tab. II). Per study, the mean time of the observations was $61.0 \pm 16.1 \mathrm{~h}$ and the mean number of observed plants was $6.4 \pm 5.4$. Around $80 \%$ of the bird species consumed whole fruits with seeds.

The duration of feeding visits of all bird species showed a significant positive relationship with the bird total length $(\mathrm{b}=$ $0.036, \mathrm{t}=4.882, \mathrm{p}<0.001)$ and with the color $\left(\mathrm{N}_{\text {conspicuous }}=24\right.$,
$\mathrm{N}_{\text {cryptic }}=15, \mathrm{~b}=0.293, \mathrm{t}=2.965, \mathrm{p}=0.005$, Fig. 1). Larger and cryptic bird species tended to spend more time per feeding visit in cerrado plants than small and conspicuous species (adjusted $\left.\mathrm{R}^{2}=0.424, \mathrm{~F}=15.020, \mathrm{p}<0.001\right)$. However, there was no interaction effect between the total length and the color of bird species on the amount of time they spent per visit $(t=1.193$, $\mathrm{p}=0.241$ ).

The relationship between the duration of feeding visits and total length of birds remained significantly positive when we considered separately the insectivorous (adjusted $\mathrm{R}^{2}=0.442$, $\mathrm{b}=0.035, \mathrm{~F}=8.921, \mathrm{p}=0.015$, Fig. 2) and the omnivorous species (adjusted $\mathrm{R}^{2}=0.406, \mathrm{~b}=0.032, \mathrm{~F}=8.197, \mathrm{p}=0.002$, Fig. 3 ). However, a significant positive relationship between visit duration and color was found only in omnivorous species $\left(\mathrm{N}_{\text {conspicuous }}=13, \mathrm{~N}_{\text {cryptic }}=9, \mathrm{~b}=0.393, \mathrm{t}=3.090, \mathrm{p}=0.006\right)$ and not for insectivorous species $\left(\mathrm{N}_{\text {conspicuous }}=7, \mathrm{~N}_{\text {cryptic }}=4, \mathrm{~b}=0.128\right.$, $\mathrm{t}=0.533, \mathrm{p}=0.608)$.

Finally, we did not find any linear relationship between the mean duration of feeding visits of birds and the length and type of the fruits (adjusted $\mathrm{R}^{2}=-0.054, \mathrm{~F}=0.861, \mathrm{p}=0.518$, Fig. 4).

\section{DISCUSSION}

In this study, we showed that large birds tend to stay longer on fruiting trees, as well as cryptic birds. These results are consistent with the predation risk hypothesis, which suggests that vulnerable bird species spend less time foraging in fruiting plants. In contrast, WheelWright (1991) did not find differences in the duration of visits to fruiting trees by tropical birds of different sizes in a lower montane forest of Monteverde, Costa Rica. He argued that the influence of predation risk in bird behavior is either more subtle or less important than previously assumed. However, his study evaluated the visits of only four bird species and, as he himself recognized, the color and size range of the birds may have been too small to reveal an effect of differential predation risk (WheELwright 1991). Here, we analyzed the time per visit of 39 fruit-eating bird species spent feeding in nine plants in the cerrado and corroborated

Table I. Fruit characteristics of Cerrado plant species and mean time of feeding visit (mean \pm standard deviation) of fruit-eating birds.

\begin{tabular}{|c|c|c|c|c|}
\hline Plant species & Fruit length (mm) & Type & Visit time (min) & Source \\
\hline Zanthoxylum rhoifolium & 5.00 & capsule & $2.1 \pm 1.5$ & Present work \\
\hline Rapanea lancifolia & 3.67 & drupe & $1.7 \pm 0.9$ & Francisco \& Galetti (2001) \\
\hline Ocotea pulchella & 8.14 & drupe & $3.4 \pm 2.6$ & Francisco \& Galetti (2002a) \\
\hline Davilla rugosa & 5.50 & capsule & $4.4 \pm 3.1$ & Francisco \& Galetti (2002b) \\
\hline Pera glabrata & 11.36 & capsule & $1.4 \pm 1.3$ & Francisco et al. (2007) \\
\hline Struthanthus concinnus & 6.88 & berry & $2.6 \pm 2.8$ & Guerra \& MarinI (2002) \\
\hline Faramea cyanea & 7.90 & drupe & $3.0 \pm 1.3$ & Melo et al. (2003) \\
\hline Copaifera langsdoffii & 14.00 & legume & $2.0 \pm 1.1$ & MOTTA-JUNIOR \& LOMBARDI (1990) \\
\hline Palicourea rigida & 6.50 & drupe & $0.6 \pm 0.1$ & WüTHERICH et al. (2001) \\
\hline
\end{tabular}

Revista Brasileira de Zoologia 25 (4): 682-688, December, 2008 

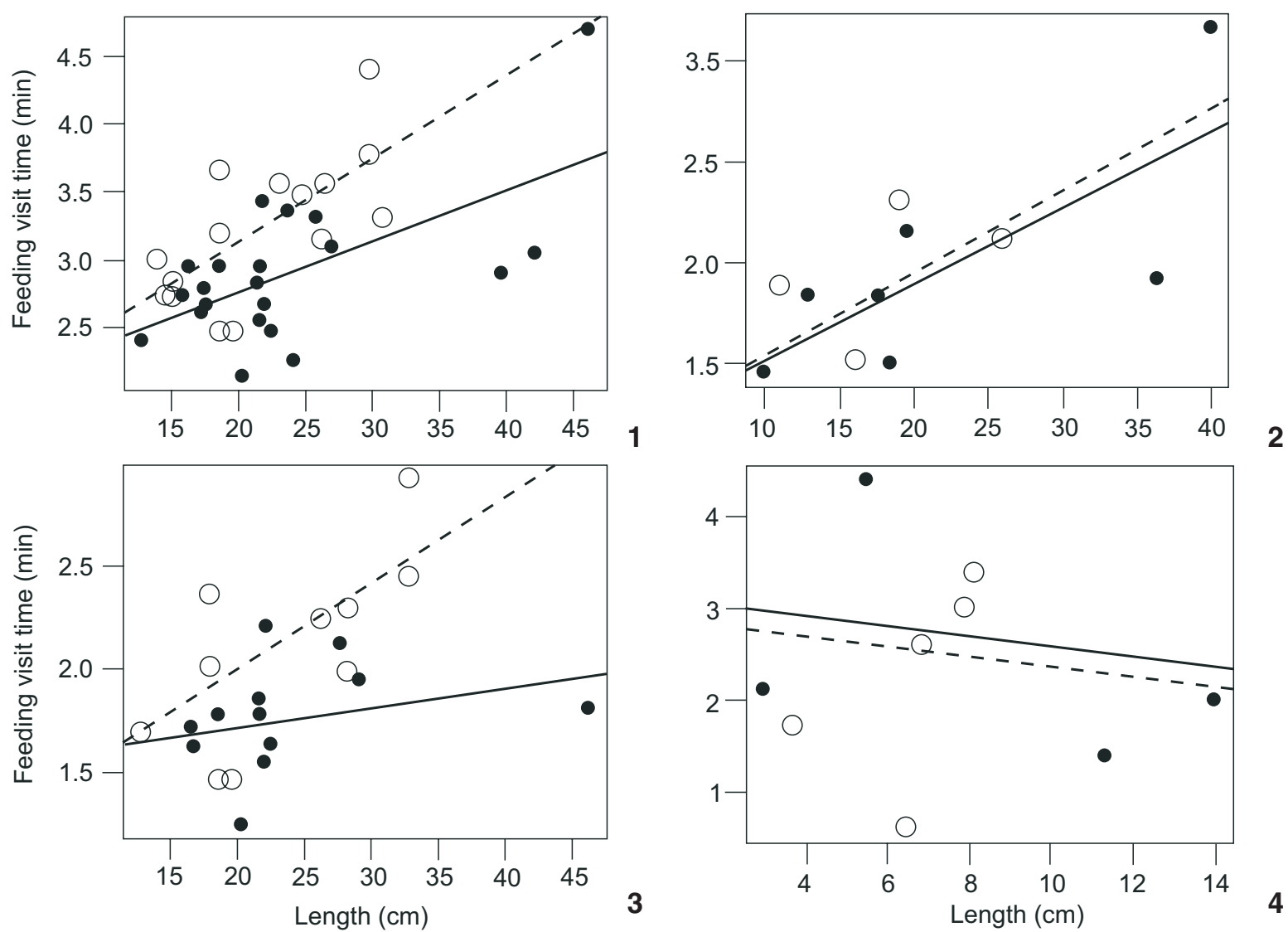

Figures 1-4. Mean feeding visit time vs. bird length of (1) fruiting-eating birds, (2) insectivorous birds, and (3) omnivorous birds in fruiting Cerrado plants. Filled and open circles are conspicuous and cryptic bird species respectively. Full and dashed lines represent respectively the contribution of the conspicuousness and crypsis of the birds in the model. In (1) and (3), both regression lines were significantly positive $(p<0.05)$, and in $(2)$, only body length showed a significant positive relationship with visit time ( $p<0.05)$. (4) Mean feeding visit time of birds per plant species vs. fruit length of Cerrado plants. Filled and open circles are dehiscent capsules and drupes respectively. Full and dashed lines represent respectively the contribution of dehiscent capsules and drupes in the linear model. Both regression lines were not significantly negative $(p=0.518)$.

the predictions of the predation risk model (Howe 1979). Our results are in accordance with earlier studies that demonstrated that the predation risk is a strong selective pressure shaping bird coloration (BAKer \& PARKer 1979, Götmark 1993).

Most visits by birds to fruiting plants in cerrado were short, comprising less than five minutes (see tables I and II). The fruits of these plants generally have less lipids than those eaten by specialized birds (JoHnson et al. 1985) and, therefore, the nutritional reward offered by such fruits seem to be small (MoERMOND \& Denslow 1985, but see Fuentes 1994). To satisfy their nutritional needs, generalist birds are expected to diversify their diets, spending less time feeding than specialized birds (Howe \& EsтавROOK 1977, JoHnson et al. 1985). The bird species included in our study are all generalists, with a broad diet that includes both insects and fruits (MotTA-JuNIOR 1990). Thus, this pattern of short visits may be a consequence of bird generalized food habits.
The lack of interaction between body size and color in determining the amount of time birds spend foraging on a single plant was unexpected. According to the predictions of the predation risk model (Howe 1979), a bird that is large and cryptic would spend more time feeding than a bird that is just large or cryptic. Nevertheless, as we discussed above, most of the birds we studied are generalists with a broad dietary spectrum (Howe \& Estabrook 1977, Johnson et al. 1985). Since large and cryptic generalist birds have to feed on a wide range of food sources to attain their nutritional needs, their visiting time in a fruiting tree is expected to be reduced.

One may ponder that there is a bias in our color analysis, since we classified cryptic and conspicuous bird species based on a human color perception. However, human color perception seems to be enough for the classification of birds in cryptic and conspicuous plumage. Although few mammalian predators of 
Table II. Mean visiting time \pm standard deviation, body length (according to SICK 1997), and color of the fruit-eating birds in Cerrado plants. (Co) conspicuous, (Cr) cryptic, (F) frugivorous, (I) insectivorous, (O) omnivorous, ( ${ }^{*}$ ) Present work, (1) Francisco \& GaletTI (2001), (2) Francisco \& Galetti (2002a), (3) Francisco \& Galetti (2002b), (4) Francisco et al. (2007), (5) Guerra \& Marini (2002), (6) Melo et al. (2003), (7) MOtTA-JUNIOR \& LOMBARDI (1990), (8) Wütherich et al. (2001).

\begin{tabular}{|c|c|c|c|c|c|c|}
\hline Species & Visit time (min) & Body length (cm) & Color & Diet & Visit number & Source \\
\hline Antilophia galeata & $1.2 \pm 0.6$ & 13.9 & Co & $\mathrm{F}$ & 27 & $2,4,5,7$ \\
\hline Camptostoma obsoletum & $1.4 \pm 0.5$ & 11.5 & $\mathrm{Cr}$ & $\mathrm{O}$ & 7 & 6,0 \\
\hline Colaptes melanochloros & $2.0 \pm 1.3$ & 26.0 & $\mathrm{Cr}$ & 1 & 21 & 2,5 \\
\hline Cyanocorax chrysops & $1.7 \pm 2.1$ & 34.0 & Co & $\mathrm{O}$ & 3 & 5 \\
\hline Cyclarhis gujanensis & $1.0 \pm 0.1$ & 16.0 & $\mathrm{Cr}$ & 1 & 3 & 5 \\
\hline Dacnis cayana & $1.2 \pm 0.3$ & 14.0 & Co & $\mathrm{O}$ & 118 & $1,4,5$ \\
\hline Elaenia chiriquensis & $1.1 \pm 1.0$ & 15.0 & $\mathrm{Cr}$ & $\mathrm{O}$ & 16 & 8,9 \\
\hline Elaenia flavogaster & $2.3 \pm 1.3$ & 15.0 & $\mathrm{Cr}$ & $\mathrm{O}$ & 37 & $1,6,8$ \\
\hline Empidonomus varius & $3.2 \pm 3.8$ & 19.0 & $\mathrm{Cr}$ & 1 & 61 & $1,3,4,5$ \\
\hline Hylophilus amaurocephalus & $1.9 \pm 0.8$ & 11.0 & $\mathrm{Cr}$ & I & 60 & 6 \\
\hline Ilicura militaris & $1.4 \pm 2.4$ & 12.5 & Co & $\mathrm{F}$ & 36 & 6 \\
\hline Megarynchus pitangua & $2.6 \pm 0.1$ & 21.5 & Co & $\mathrm{O}$ & 18 & 2,7 \\
\hline Mimus saturninus & $3.8 \pm 2.8$ & 25.0 & $\mathrm{Cr}$ & $\mathrm{O}$ & 60 & 1,3 \\
\hline Mionectes rufiventris & $1.5 \pm 0.5$ & 14.0 & Co & $\mathrm{O}$ & 8 & 6 \\
\hline Molothrus bonariensis & 0.7 & 20.0 & Co & $\mathrm{F}$ & 7 & 9 \\
\hline Myiarchus ferox & $0.9 \pm 0.6$ & 18.5 & Co & 1 & 3 & 5 \\
\hline Myiarchus swainsoni & $2.7 \pm 0.8$ & 19.5 & Co & 1 & 19 & 4 \\
\hline Myiarchus tyrannulus & $1.8 \pm 0.5$ & 17.75 & Co & 1 & 28 & $1,2,3,8$ \\
\hline Myiodynastes maculatus & $3.0 \pm 1.5$ & 20.5 & $\mathrm{Cr}$ & $\mathrm{O}$ & 11 & $1,2,3$ \\
\hline Myiozetetes similis & $1.8 \pm 1.3$ & 17.5 & Co & $\mathrm{O}$ & 16 & $1,3,8$ \\
\hline Nemosia pileata & $1.8 \pm 1.3$ & 13.0 & Co & 1 & 6 & 2,5 \\
\hline Phaeomyias murina & $1.6 \pm 0.9$ & 12.0 & $\mathrm{Cr}$ & $\mathrm{F}$ & 31 & 6 \\
\hline Phyllomyias fasciatus & $1.4 \pm 0.5$ & 12.0 & $\mathrm{Cr}$ & $\mathrm{F}$ & 7 & 6 \\
\hline Piranga flava & $1.6 \pm 0.4$ & 17.5 & Co & $\mathrm{O}$ & 20 & $1,5,6$ \\
\hline Pitangus sulphuratus & $2.1 \pm 0.5$ & 22.5 & Co & $\mathrm{O}$ & 30 & $1,3,8$ \\
\hline Ramphocelus carbo & $1.3 \pm 1.5$ & 18.0 & Co & $\mathrm{O}$ & 12 & 1,5 \\
\hline Schistochlamys ruficapillus & $2.9 \pm 0.1$ & 17.8 & Co & $\mathrm{O}$ & 32 & $1,3,4,8$ \\
\hline Serpophaga subcristata & 0.9 & 10.0 & Co & 1 & 7 & 8 \\
\hline Tachyphonus coronatus & $1.1 \pm 0.6$ & 17.7 & Co & $\mathrm{O}$ & 6 & 1 \\
\hline Tangara cayana & $1.3 \pm 0.6$ & 14.2 & Co & $\mathrm{O}$ & 92 & $1,2,4,5,8,9$ \\
\hline Thraupis episcopus & 0.6 & 16.5 & Co & $\mathrm{O}$ & 8 & 9 \\
\hline Thraupis sayaca & $1.6 \pm 0.5$ & 17.5 & Co & $\mathrm{O}$ & 78 & $1,2,4,5,8$ \\
\hline Turdus amaurochalinus & $2.2 \pm 1.1$ & 21.9 & $\mathrm{Cr}$ & $\mathrm{O}$ & 78 & $3,5,7,8$ \\
\hline Turdus leucomelas & $3.2 \pm 2.8$ & 22.0 & $\mathrm{Cr}$ & $\mathrm{O}$ & 163 & $2,3,4,5,7,8$ \\
\hline Turdus rufiventris & $5.9 \pm 3.7$ & 25.0 & $\mathrm{Cr}$ & $\mathrm{O}$ & 17 & 3,8 \\
\hline Tyrannus melancholicus & $2.0 \pm 0.9$ & 36.3 & Co & 1 & 94 & $1,2,3,9$ \\
\hline Tyrannus savana & $7.1 \pm 11.1$ & 40.0 & Co & 1 & 36 & 3 \\
\hline Vireo olivaceus & $3.5 \pm 4.9$ & 15.0 & $\mathrm{Cr}$ & $\mathrm{O}$ & 71 & $2,4,5$ \\
\hline Zonotrichia capensis & $1.9 \pm 1.3$ & 15.0 & Co & $\mathrm{F}$ & 28 & 5 \\
\hline
\end{tabular}

Revista Brasileira de Zoologia 25 (4): 682-688, December, 2008 
birds have been proved to have color vision, there is some evidence supporting the notion that mammals have color sensitivity and are not entirely color blind (see BAKER \& PARKER 1979 for references). However, the predation risk model should also predict the feeding visit time when only avian predators are considered. In these sense, bird predators not only have color vision, but also perceive ultraviolet light. Nevertheless, measurements of 312 bird species from 142 families showed that ultraviolet reflectance from the plumage is ubiquitous in birds and no visual colour class represented in bird plumages was strongly associated with ultraviolet reflectance (EATON \& LANYON 2003). Consequently, the visual color of bird plumages may be most important feature determining prey conspicuousness to an avian predators.

The diet of bird species and the mode in which birds manipulate fruits may influence the duration of feeding visits (Howe \& Estabrook 1977, Johnson et al. 1985). As insectivorous birds include a small proportion of fruits in their diets (MоттAJUNIOR 1990), we did not expect visit duration of insectivorous to be positively related to body length. However, our analysis with insectivorous and omnivorous birds showed the same consistent linear relationship predicted by the predation risk model, even though crypsis may not to be related to duration of feeding visit of insectivorous birds. Large fruits may increase time of fruit manipulation by birds and, consequently, the time of their feeding visit. Nevertheless, we did not find any relationship between fruits characteristics and duration of feeding visit. Therefore, it seems that the risk of a predator attack (and not the time of fruit manipulation) is the key factor influencing the duration of bird feeding visits in cerrado plants.

Finally, our results indicate that the time fruit-eating birds spend foraging may be determined by the vulnerability of the bird species to predation. This should play an important role on the success of establishment of bird-dispersed plants, since short feeding visits produce less clumped distributions of seeds, reducing consequently density-dependent mortality of seedlings (Howe \& SMallwood 1982). However, other factors may also influence the feeding visit time. Birds feeding in mixed flocks and with vigilant leaders are expected to increase the feeding visit time (KenWard 1978, Ragusa-NetTo 2002). Further studies should include this information on analyses of the predation risk model, as well as other potential factors such as bird species relatedness and plumage ultraviolet reflectance.

\section{ACKNOWLEDGMENTS}

We are grateful to Capes for the scholarship granted to first author; to Mayla W. Valenti, for helping in field work; and to two anonymous reviewers for useful comments on the manuscript.

\section{LITERATURE CITED}

Augspurger, C.K. \& C.K. Kelly. 1984. Pathogen mortality of tropical tree seedlings: experimental studies of the effects of dispersal distance, seedling density, and light conditions.
Oecologia 61 (2): 211-217.

BAKER, R.R., \& G.A. PARKer. 1979. The evolution of bird coloration. Philosophical Transactions of the Royal Society of London B 287 (1018): 63-130.

Bridgewater, S.; J.A. Ratter \& J.F. Ribeiro. 2004. Biogeographic PATTERNS, $ß$-diversity and dominance in the cerrado biome o Brazil. Biodiversity and Conservation 13 (12): 2295-2318.

Das Chagas e Silva, F. \& L.H. Soares-Silva. 2000. Arboreal flora of THE GODOY FOREST STAte park, Londrina, PR, Brazil. Edinburgh Journal of Botany 57 (1): 107-120.

Eaton, M.D. \& S.M. LANYon. 2003. The ubiquity of avian ultraviolet plumage reflectance. Proceedings of the Royal Society of London B 270 (1525): 1721-1726.

Francisco, M.R. \& M. Galetti. 2001. Frugivoria e dispersão de sementes de Rapanea lancifolia (Myrsinaceae) por aves numa área de cerrado do Estado de São Paulo, sudeste do Brasil. Ararajuba 9 (1): 13-19.

Francisco, M.R. \& M. Galetti. 2002a. Aves como potenciais dispersoras de sementes de Ocotea pulchella Mart. (Lauraceae) numa área de vegetação de cerrado do sudeste brasileiro. Revista Brasileira de Botânica 25 (1): 11-17.

Francisco, M.R. \& M. Galetti. 2002b. Consumo dos frutos de Davilla rugosa (Dilleniaceae) por aves numa área de cerrado em São Carlos, Estado de São Paulo. Ararajuba 10 (2): 193198.

Francisco, M R.; V.O. LunARdi \& M. Galetti. 2007. Bird attributes, plant characteristics, and seed dispersal of Pera glabrata Schott (Euphorbiaceae) in a disturbed cerrado area. Brazilian Journal of Biology 67 (4): 627-624.

Fuentes, M. 1994. Diets of fruit-eating birds: what are the causes of interspecific differences? Oecologia 97 (1): 134-142.

Gotelli, N.J. \& A.M. ElLison. 2004. A primer of ecological statistics. Sunderland, Sinauer Associates, 479p.

Götmark, F. 1993. Conspicuous coloration in male birds is favoured by predation in some species and disfavoured in others. Proceedings of the Royal Society of London B 253 (1337): 143-146.

Gottsberger, G. \& I. Silberbauer-Gottsberger. 2006a. Life in the cerrado: a South American tropical seasonal vegetation. Vol. 1. Origin, structure, dynamics and plant use. Ulm, Reta Verlag, 277p.

Gottsberger, G. \& I. Silberbauer-Gottsberger. 2006b. Life in the cerrado: a South American tropical seasonal vegetation. Pollination and seed dispersion. Ulm, Reta Verlag, vol. 2, $383 p$.

Guerra, T.J. \& M.A. Marini. 2002. Bird frugivory on Struthanthus concinnus (Loranthaceae) in Southeastern Brazil. Ararajuba 10 (2): 187-192.

Howe, H.F. 1979. Fear and frugivory. American Naturalist 114 (6): 925-931.

Howe, H.F. \& G.F. ЕsтавRoок. 1977. On intraspecific competition for avian dispersers in tropical trees. American Naturalist 111 (981): 817-832. 
Howe, H.F. \& J. Smallwood. 1982. Ecology of seed dispersal. Annual Review of Ecology and Systematics 13 (1): 201-228.

Johnson, R.A.; M.F. Wilson; J.N. Thompson \& R. Bertin. 1985. Nutritional values of wild fruits and consumption by migrant frugivorous birds. Ecology 66 (3): 819-827.

KENWARD, R.E. 1978. Hawks and doves: factors affecting success and selection in goshawk attacks on wood-pigeons. Journal of Animal Ecology 47 (2): 449-460.

Melo, C.; E.C. Bento \& P.E. Oliveira. 2003. Frugivory and dispersal of Faramea cyanea (Rubiaceae) in cerrado wood plant formations. Brazilian Journal of Biology 63 (1): 75-82.

Merilaita, S.; A. Lyytinen \& J. Mappes. 2001. Selection for cryptic coloration in a visually heterogeneous habitat. Proceedings of the Royal Society of London B 268 (1479): 1925-1929.

Moermond, T.C. \& J.S. Denslow. 1985. Neotropical frugivores: patterns of behaviour, morphology and nutrition with consequences for fruit selection. Ornithological Monographs 36: 865-897.

MotTa-Junior, J.C. 1990. Estrutura trófica e composição das avifaunas de três hábitats terrestres na região central do estado de São Paulo. Ararajuba 1 (1): 65-71.

MotTa-Junior, J.C. \& J.A. Lombardi. 1990. Aves como agentes dispersores da copaíba (Copaifera langsdorffii, Caesalpiniaceae) em São Carlos, estado de São Paulo. Ararajuba 1 (1): 105-109.

Neto, R.M.R.; L.F. Watzlawick; M.V.W. Caldeira \& E.R. SCHOENInger. 2002. Análise florística e estrutural de um frag- mento de floresta ombrófila mista montana, situado em Criúva, RS - Brasil. Ciência Florestal 12 (1): 29-37.

Oliveira-Filho, A.T.; N. Curi, E.A. Vilela \& D.A. Carvalho. 2001. Variation in tree community composition and structure with changes in soil properties within a fragment of semideciduos forest in south-eastern Brazil. Edinburgh Journal of Botany 58 (1):139-158.

Pratt, T.K. \& E.W. Stiles. 1983. How long fruit-eating birds stay in the plants where they feed: implications for seed dispersal. American Naturalist 122 (6): 797-805.

Ragusa-Netto J. 2002. Vigilance towards raptors by nuclear species in bird mixed flocks in a Brazilian savannah. Studies on Neotropical Fauna and Environment 37 (3): 219-226.

Schoener, T.W. 1971. Theory of feeding strategies. Annual Review of Ecology and Systematics 2 (1): 369-404.

SICK, H. 1997. Ornitologia brasileira. Rio de Janeiro, Editora Nova Fronteira, 912p.

SiLVA, L.L. \& A.A.S. PAOLI. 2000. Caracterização morfo-anatômica da semente de Zanthoxylum rhoifolium Lam.- Rutaceae. Revista Brasileira de Sementes 22 (2): 250-256.

Wheelwright, N.T. 1991. How long do fruit-eating birds stay in the plants where they feed? Biotropica 23 (1): 29-40.

Wütherich, D.; A. Azócar; C. Garcia-Nuñez \& J. Silva. 2001. Seed dispersal in Palicourea rigida, a common treelet species from Neotropical savannas. Journal of Tropical Ecology 17 (3): 449-458.

Submitted: 15.VI.2008; Accepted: 02.XII.2008.

Editorial responsibility: Glauco Machado 